\title{
Sesquiterpene Aminoquinones, from a Marine Sponge, Induce Erythroid Differentiation in Human Chronic Myelogenous Leukemia, K562 Cells
}

\author{
Shunji Aoki,${ }^{a}$ Dexin Kong,${ }^{a}$ Kouhei Matsui,${ }^{a}$ Rachmaniar Rachmat, ${ }^{b}$ and Motomasa Kobayashi $* a$ \\ ${ }^{a}$ Graduate School of Pharmaceutical Sciences, Osaka University; 1-6, Yamada-oka, Suita, Osaka 565-0871, Japan: and \\ ${ }^{b}$ Research and Development Centre for Oceanology, LIPI; JL. Pasir Putih I, Ancol Timur, Jakarta 11048, Indonesia. \\ Received January 15, 2004; accepted May 19, 2004
}

\begin{abstract}
A new sesquiterpene aminoquinone, 5-epi-smenospongorine, together with nine known sesquiterpene quinone/phenols, was isolated as differentiation-inducing substances to $\mathrm{K562}$ cells into erythroblast from the marine sponge Dactylospongia elegans. The structure-activity relationship study of these compounds clarified that the quinone skeleton is indispensable and the amino group plays an important role for their differentiation-inducing activity to $\mathrm{K} 562$ cells into erythroblast.
\end{abstract}

Key words 5-epi-smenospongorine; erythroid differentiation; structure-activity relationship; K562 cells; marine sponge

Despite the various cancer therapeutic methods such as chemotherapy, which are being carried out clinically, cancer remains to be a serious and, in most cases, fatal disease. Chemotherapeutic drugs affect not only tumor cells but also proliferative normal cells such as bone marrow cells and result in serious side effects. To solve this problem, several other alternative therapeutic methods are being developed. The differentiation-induction therapy, in which tumor cells are differentiated to normal cells, seems to be one promising therapy. As a good example of differentiation inducer, ATRA (all-trans-retinoic acid) has shown superior therapeutic effect on acute promyelocytic leukemia (APL), which is unresponsive to conventional chemotherapeutic drugs. ${ }^{1)}$ However, several kinds of leukemia such as human chronic myelogenous leukemia (CML) are unresponsive to ATRA. So, development of new differentiation inducers has been required.

As a part of our exploratory research of bioactive substances from marine organisms, we have been searching for new differentiation inducers to tumor cells and have found several inducers to ATRA-nonresponsive CML (K562 cells) or murine neuroblastoma (Neuro 2A cells) from marine sponges. ${ }^{2-4)}$ Recently, we have isolated from a marine sponge $^{5)}$ a sesquiterpene aminoquinone, smenospongine (4), which induces differentiation of K562 cells into erythroblasts. Study on its action mechanism showed that smenospongine induced arrest of the cell cycle at the G1 phase and increased expression of $\mathrm{p} 21$ protein, a Cip1/Waf1 cdk (cyclin dependent kinase) inhibitor. ${ }^{5)}$ This interesting action of smenospongine led us to continue further study, and we isolated ten sesquiterpene quinones/phenol analogues from the same marine sponge, including a new compound named 5-epi-smenospongorine (1). In this paper, the structure-activity relationship of these sesquiterpene quinones is discussed.

\section{Results and Discussion}

Chemical Structures of 5-epi-Smenospongorine (1) and the Analogues The nine sesquiterpene quinone/phenols (2-10) together with a new compound named 5-epismenospongorine (1) were isolated from the marine sponge Dactylospongia elegans. (Fig. 1) Compounds 2-10 were identified as smenospongorine, ${ }^{6,7)}$ 5-epi-smenospongine, ${ }^{6,8)}$ smenospongine, ${ }^{6,7,9)} 5$-epi-smenospongidine, $\left.{ }^{6}\right)$ smenospongidine, ${ }^{7)}$ 5-epi-ilimaquinone, ${ }^{6}$ ilimaquinone, ${ }^{7)}$ dictyoceratin-
$\mathrm{C},{ }^{8)}$ and smenospondiol, ${ }^{6,7)}$ respectively, by comparison of the FAB-MS, ${ }^{1} \mathrm{H}$ - and ${ }^{13} \mathrm{C}-\mathrm{NMR}$ data with those of the authentic compounds.

The molecular formula of the new compound, 5-epismenospongorine (1), was determined as $\mathrm{C}_{25} \mathrm{H}_{37} \mathrm{NO}_{3}$ by HRFAB-MS analysis. Compound 1 showed absorption bands ascribable to amino $\left(3270 \mathrm{~cm}^{-1}\right)$ and carbonyl $\left(1644 \mathrm{~cm}^{-1}\right)$ groups in the IR spectrum. The ${ }^{1} \mathrm{H}-\mathrm{NMR}$ spectrum of 1 showed the signals assignable to two tertiary methyls $(\delta 1.06$, 0.87 , both $\mathrm{s})$, three secondary methyls $(\delta 0.99,6 \mathrm{H} \mathrm{d}$, $J=6.7 \mathrm{~Hz} ; \delta 0.92, \mathrm{~d}, J=6.1 \mathrm{~Hz})$, a benzylic methylene $(\delta$ 2.43 and $2.53, \mathrm{AB}$ quartet, $J=13.8 \mathrm{~Hz}$ ), an exomethylene ( $\delta$ $4.70,4.67$, both s), and an olefinic proton $(\delta 5.38, \mathrm{~s})$. The ${ }^{1} \mathrm{H}-$ and ${ }^{13} \mathrm{C}$-NMR signals due to the decalin part and the quinone part in 1 were closely similar to those of 5-epi-smenospongidine $(\mathbf{5})^{6)}$ and smenospongorine (2), ${ }^{7}$ respectively. Then, it is presumed that compound $\mathbf{1}$ is a hybrid of 5-epismenospongidine (5) and smenospongorine (2). $\left.{ }^{8}\right)$ This presumption that compound $\mathbf{1}$ is an epimer at the $\mathrm{C}-5$ position of smenospongorine (2) was further confirmed by nuclear overhauser effect spectroscopy (NOESY) analysis of both compounds 1 and 2 . Thus, the correlations between $\mathrm{H}-12$ and $\mathrm{H}-$ 10 for compound 1 and between H-12 and H-14 for compound $\mathbf{2}$ were found. Based on these evidences, compound $\mathbf{1}$ was determined as 5-epi-smenospongorine as shown in Fig. 1.

Erythroid Differentiation of K562 Cells Induced by 5-
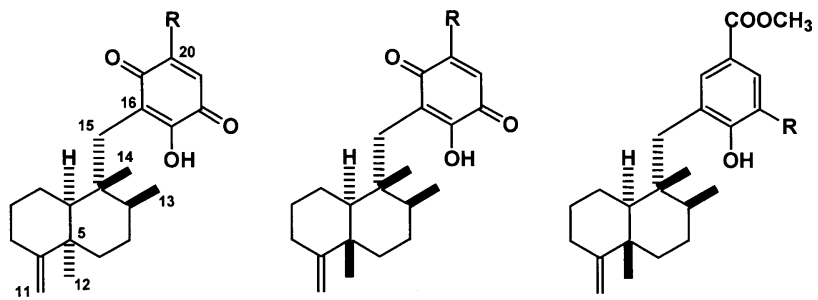

5-epi-smenospongorine (1): $\mathrm{R}=\mathrm{NH}-\mathrm{CH}_{2} \mathrm{CH}\left(\mathrm{CH}_{3}\right)_{2}$

5-epi-smenospongine (3): $\mathrm{R}=\mathrm{NH}_{2}$

5-epi-smenospongidine (5): $\mathrm{R}=\mathrm{NH}-\mathrm{CH}_{2} \mathrm{CH}_{2} \mathrm{Ph}$

5-epi-ilimaquinone (7): $\mathrm{R}=\mathrm{OCH}_{3}$

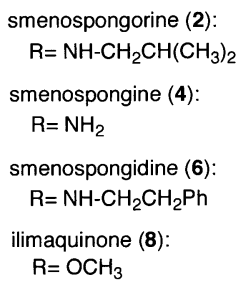

dictyoceratin-C (9): $\mathrm{R}=\mathrm{H}$

smenospondiol (10): $\mathrm{R}=\mathrm{OH}$

Fig. 1. Chemical Structures of 5-epi-Smenospongorine and the Analogues 


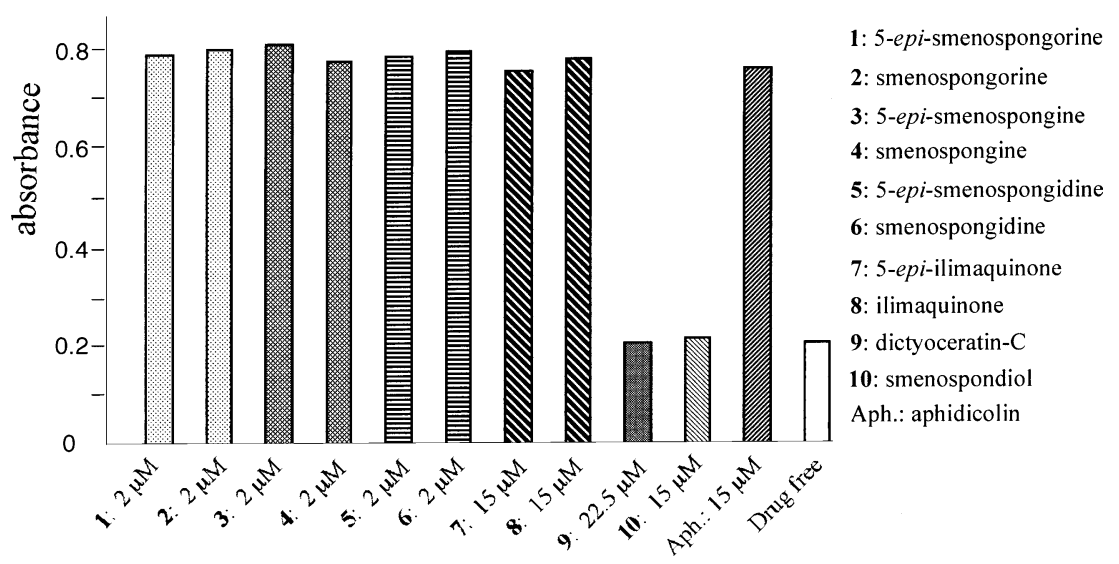

Fig. 2. The Induction of Hemoglobin Production by 5-epi-Smenospongorine and the Analogues

A suspension of $4 \times 10^{4}$ cells of K562 cells was treated with a testing sample and cultured for $4 \mathrm{~d}$. The collected cells were treated with diaminofluorene solution and $3 \%$ hydrogen peroxide. The absorbance at $630 \mathrm{~nm}$ was measured by a microplate reader.

epi-Smenospongorine and the Related Compounds The differentiation-inducing activities of these compounds were evaluated by the induction of hemoglobin production in K562 cells. Thus, pseudo-peroxidase activity of hemoglobin was measured by the colorimetric assay using diaminofluorene. The lowest concentrations of each compound $(\mathbf{1}-\mathbf{8})$ indicating similar differentiation-inducing activity are shown in Fig. 2, respectively. And, the highest concentrations showing no cytotoxicity were chosen for the two inactive sesquiterpene phenols, 9 and 10. Firstly, each of six sesquiterpene aminoquinones (1-6) exhibited similar differentiation-inducing activity, which is stronger than that of aphidicolin, a well-known differentiation-inducing agent of K562 cells into erythroblasts. ${ }^{10)}$ Secondly, compounds 9 and 10, which does not have quinone function, showed no activity. Thirdly, compounds 7 and $\mathbf{8}$ showed differentiation-inducing activities at the higher concentration than those of $\mathbf{1 - 6}$. On the basis of these structure-activity relationship studies, the following evidences were obtained. 1) The quinone structure is indispensable. 2) The amino group should play an important role. 3) The substituents at the amino group are not crucial. 4) The configuration at the C-5 in sesquiterpene part is not important.

So far, these sesquiterpene quinone/phenols have been reported to exhibit anti-microbial, anti-HIV, anti-malarial, and cytotoxic activities..$^{9,11,12)}$ In this study, we clarified that these sesquiterpene aminoquinones exhibit differentiation-inducing activity to K562 cells into erythroblasts. The clinical application of Glivec ${ }^{13}$ ) (a synthetic compound targeting Bcr-Abl (breakpoint cluster region-Abelson leukemia sequence), ${ }^{14}$ ) which has been recognized as the cause of CML) has provided light on a cure for this disease. However, the use of Glivec over extended periods caused drug-resistance in patients, and new types of differentiation inducers for CML have been required. These sesquiterpene aminoquinones having differentiation-inducing activities might be a promising agent for the treatment of CML.

\section{Experimental}

Materials Marine sponge Dactylospongia elegans was collected at West Flores, Indonesia in 2001. 2,7-Diaminofluorene and aphidicolin were purchased from Wako Pure Chemical Industries Co. Ltd.

Cell Lines Human chronic myelogenous leukemia cell line K562 was provided by RIKEN Cell Bank and routinely maintained in RPMI medium
Table 1. ${ }^{1} \mathrm{H}$ - and ${ }^{13} \mathrm{C}$-NMR Data for 5-epi-Smenospongorine (1)

\begin{tabular}{rrlrcl}
\hline \hline No. & $\left.\delta_{\mathrm{C}}{ }^{a}\right)$ & \multicolumn{1}{c}{$\delta$ (mult., $J(\mathrm{~Hz}))^{b)}$} & No. & \multicolumn{1}{c}{$\delta_{\mathrm{C}}$} & $\delta$ (mult., $J(\mathrm{~Hz}))$ \\
\hline 1 & 22.5 & $2.13(\mathrm{~m})$ & 11 & 105.7 & $4.70(\mathrm{~s})$ \\
& & $1.83(\mathrm{~m}$, overlapped) & & & $4.67(\mathrm{~s})$ \\
2 & 25.0 & $1.77(\mathrm{~m})$ & 12 & 33.1 & $1.06(\mathrm{~s})$ \\
& & $1.68(\mathrm{~m})$ & 13 & 18.6 & $0.92(\mathrm{~d}, 6.1)$ \\
3 & 32.9 & $2.43(\mathrm{~d}, 13.8)$ & 14 & 18.3 & $0.87(\mathrm{~s})$ \\
& & $2.10(\mathrm{~m})$ & 15 & 32.0 & $2.53(\mathrm{~d}, 13.8)$ \\
4 & 153.6 & & & & $2.43(\mathrm{~d}, 13.8)$ \\
5 & 39.5 & & 16 & 113.7 & \\
& & & 17 & 157.3 & \\
6 & 37.9 & $1.99(\mathrm{~m})$ & 18 & 178.4 & \\
& & $1.13(\mathrm{~m})$ & 19 & 91.6 & $5.38(\mathrm{~s})$ \\
7 & $27.9^{c)}$ & $1.84(\mathrm{~m}$, overlapped) & 20 & 150.6 & \\
8 & 39.3 & $1.51(\mathrm{~m})$ & 21 & 182.7 & \\
9 & 44.4 & & $1^{\prime}$ & 50.4 & $2.99(\mathrm{~m}, 6.4)$ \\
10 & 48.4 & $1.20(\mathrm{~m})$ & $2^{\prime}$ & $\left.27.7^{c}\right)$ & $1.96(\mathrm{~m})$ \\
& & & $3^{\prime}, 4^{\prime}$ & 20.3 & $0.99(\mathrm{~d}, 6.7)$ \\
\hline
\end{tabular}

a) $125 \mathrm{MHz}$ in $\mathrm{CDCl}_{3}$. b) $500 \mathrm{MHz}$ in $\mathrm{CDCl}_{3}$. c) Interchangable.

supplemented with $10 \%$ fetal bovine serum, $100 \mu \mathrm{g} / \mathrm{ml}$ kanamycin, and $0.44 \mathrm{mg} / \mathrm{ml}$ glutamine at $37{ }^{\circ} \mathrm{C}$ in a humidified atmosphere of $5 \% \mathrm{CO}_{2}$.

Extraction and Isolation The frozen marine sponge $(2.6 \mathrm{~kg}$, wet weight) was cut into pieces and soaked in methanol overnight. The resulting methanol extract was subjected to solvent partition to give hexane, $90 \%$ methanol, $n-\mathrm{BuOH}$, and $\mathrm{H}_{2} \mathrm{O}$ phases. The $90 \%$ methanol phase was evaporated under reduced pressure to give $12 \mathrm{~g}$ of $90 \% \mathrm{MeOH}$ extract. The $90 \%$ methanol extract $(2 \mathrm{~g})$, which exhibited differentiation-inducing activity, was separated by $\mathrm{SiO}_{2}$ column (hexane-AcOEt-acetone-MeOH) to give three fractions [Fr. A $(0.42 \mathrm{~g})$, Fr. B $(0.73 \mathrm{~g})$, Fr. C $(0.83 \mathrm{~g})]$. The active Fr. C was further separated by ODS column (Cosmosil ODS, $\mathrm{MeOH}-\mathrm{H}_{2} \mathrm{O}$ ) and reversed-phase HPLC (CAPCELL PAK C18 UG120, 70\% aq. MeOH- $0.1 \%$ diethylamine) to obtain 1 (3 $\mathrm{mg}, 0.15 \%$ from the $90 \% \mathrm{MeOH}$ extract), 2 (5 mg, 0.25\%), 3 (19 mg, 0.95\%), 4 (9 mg, 0.45\%), 5 (3 mg, 0.15\%), 6 ( $4 \mathrm{mg}, 0.20 \%), 7$ ( $5 \mathrm{mg}, 0.25 \%), 8$ ( $3 \mathrm{mg}, 0.15 \%)$. The inactive Fr. A and Fr. B were also separated by ODS column $\left(\mathrm{MeOH}-\mathrm{H}_{2} \mathrm{O}\right)$ or HPLC (Cosmosil 5SL, hexane-AcOEt $=7: 1)$ to obtain $9(20 \mathrm{mg}, 1 \%)$ and $\mathbf{1 0}(17 \mathrm{mg}, 0.85 \%)$.

5-epi-Smenospongorine (1): $[\alpha]_{\mathrm{D}}+23^{\circ}\left(c=0.06, \mathrm{CHCl}_{3}\right)$. HR-FAB-MS $m / z$ : Calcd for $\mathrm{C}_{25} \mathrm{H}_{38} \mathrm{NO}_{3}\left([\mathrm{M}+\mathrm{H}]^{+}\right)$: 400.2852; Found: 400.2842. UV $\lambda_{\max }$ $(\mathrm{EtOH}) \mathrm{nm}(\varepsilon): 320$ (9800), 205 (20500). IR (KBr): $3270,1644 \mathrm{~cm}^{-1} \cdot{ }^{1} \mathrm{H}-$ and ${ }^{13} \mathrm{C}$-NMR: as shown in Table 1.

Induction of Hemoglobin Production in K562 Cells For the evaluation of hemoglobin production in K562 cells, pseudo-peroxidase activity of hemoglobin was measured by the colorimetric assay using diaminofluorene. ${ }^{2)}$ The suspension of $\mathrm{K} 562$ cells $\left(4 \times 10^{4}\right.$ cells $/ 2 \mathrm{ml} /$ well $)$ was placed in a 24-well plate. After addition of $10 \mu 1$ of the DMSO solution of the testing sample, the culture was incubated at $37^{\circ} \mathrm{C}$ under $5 \% \mathrm{CO}_{2}$ atmosphere for $4 \mathrm{~d}$. The culture medium was centrifuged at $3000 \mathrm{~g}$ for $3 \mathrm{~min}$, and the resulting supernatant was removed. After addition of $50 \mu \mathrm{l}$ of ultra-pure water, the 
lysed cells were treated with $100 \mu$ of the diaminofluorene solution [5 mg of diaminofluorene was dissolved in $1 \mathrm{ml}$ of the $90 \%$ acetic acid and Tris- $\mathrm{HCl}$ buffer $(\mathrm{pH} 7.5)(10: 1)$ solution] and $10 \mu \mathrm{l}$ of $3 \%$ hydrogen peroxide and then kept for $30 \mathrm{~min}$ in the dark. The absorbance at $630 \mathrm{~nm}$ was measured by a microplate reader. The drug-untreated cells were used as the negative control.

Acknowledgements The authors are grateful to Prof. R. W. M. Soest, Zoologisch Museum, University of Amsterdam, for identification of the sponge. The authors are also grateful to the Takeda Science Foundation, the Houansha Foundation, the Tokyo Biochemical research Foundation, the Uehara Memorial Foundation, and the Ministry of Education, Culture, Sports, Science, and Technology of Japan for financial support.

\section{References}

1) Parkinson D. R., Smith M. A., Cheson B. D., Stevenson H. C., Friedman M. A., Semin. Oncol., 19, 734-741 (1992).

2) Aoki S., Higuchi K., Isozumi N., Matsui K., Miyamoto Y., Itoh N., Tanaka K., Kobayashi M., Biochem. Biophys. Res. Commun., 282, 426- 431 (2001).

3) Aoki S., Matsui K., Tanaka T., Wei H., Kobayashi M., Biochem. Biophys. Res. Commun., 289, 558-563 (2001).
4) Aoki S., Wei H., Matsui K., Rachmat R., Kobayashi M., Bioorg. Med. Chem., 11, 1969-1973 (2003).

5) Aoki S., Kong D., Matsui K., Kobayashi M., Anticancer Drugs, 15, 363-369 (2004)

6) Rodriguez J., Quinoa E., Riguera R., Peters B. M., Abrell L. M., Crews P., Tetrahedron, 48, 6667-6680 (1992).

7) Kondracki M. L., Guyot M., Tetrahedron, 45, 1995-2004 (1989).

8) Kwak J. H., Schmitz F. J., Kelly M., J. Nat. Prod., 63, 1153-1156 (2000).

9) Kondracki M. L., Guyot M., Tetrahedron Lett., 28, 5815-5818 (1987).

10) Murate T., Kagami Y., Hotta T., Yoshida T., Saito H., Yoshida S., Exp. Cell Res., 191, 45-50 (1990).

11) Loya S., Tal R., Kashman Y., Hizi A., Antimicrob. Agents Chemother, 34, 2009-2012 (1990).

12) Goclik E., Konig G. M., Wright A. D., Kaminsky R., J. Nat. Prod., 63, $1150-1152(2000)$.

13) Dan S., Naito M., Tsuruo T., Cell Death Differ., 5, 710-715 (1998).

14) De Klein A., Van Kessel A. G., Grosveld G., Bartram C. R., Hagemeijer A., Bootsma D., Spurr N. K., Heisterkamp N., Groffen J., Stephenson J. R., Nature (London), 300, 765-767 (1982). 